\title{
Competency Based Education - Current Global Practices
}

\author{
Hernández-de-Menéndez, Marcela and Morales-Menendez, Ruben
}

Tecnológico de Monterrey, México

\begin{abstract}
Competency Based Education (CBE) is considered an alternative to face the lack of individuals with the appropriate labour abilities. A state of the art on $C B E$ in terms of the practices being performed by main worldwide universities/colleges is presented. Main promoted competencies include effective communication, critical thinking and lifelong learning. Also, teaching and practice activities are determined such as real life situations and simulations. Regarding competency assessment techniques, a mix of them is used to guarantee the desired competency level. Achievements of competencies are reported with a pass or not pass grade and with narrative transcripts. CBE benefits from student's perspective are also determined.

The main advantage of $C B E$ is that measures what a student can do after completing a program. It is also flexible, as universities/colleges of any sizelage can incorporate it at different levels, which depends on their resources and strategies. Even though CBE has proven to solve a global problem, the gap between the supply and demand of skillful people can only be reduced if all the concerned parties work together in a coordinated manner.
\end{abstract}

Keywords: CBE, Competency Teaching and Assessment Techniques 


\section{Introduction}

Competency Based Education ( $C B E$ ) is considered an alternative to face the lack of individuals with the appropriate labour abilities (Dawson, Dean, Johnson, \& Koronkiewicz, 2014). It is defined as a "knowledge based methodology which concentrates on measuring what a person can actually do as a result of learning" (Umbleja, Kukk, \& Jaanus, 2013, p.552). $C B E$ importance lies in the fact that it contributes to prepare people to add value to organizations and also to adapt to the global economic demands.

As we reviewed the foundations of $C B E$ (Hernández \& Morales, 2016), strategic knowledge was integrated such as the fundamentals of competency concept, the competencies students of different levels and areas must acquire to succeed and the occupational trends with related skill demands. A state of the art on $C B E$ in terms of the practices of main universities and colleges worldwide will be presented. Papers, reports and official sites of $C B E$ organizations were analyzed to determine their characteristics. Also, discussions around this project based on several years of consulting, researching and teaching activities were performed. The outline of the paper is as follows: in Section 2, the different levels of $C B E$ implementation are explained. Section 3 presents an analysis of the $C B E$ models of main universities/colleges worldwide. Section 4 describes what is going on in $C B E$. Section 5 concludes the paper.

\section{CBE Classification Centered on Implementation Levels}

Universities and colleges that have already adopted a $C B E$ approach exhibit different levels of implementation based on their strategy. It can be seen like a continuum, Fig. 1.

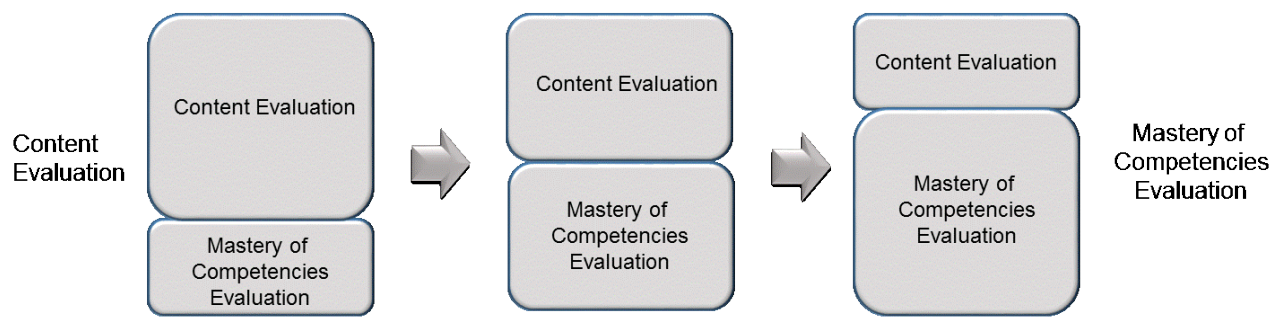

Figure 1. CBE content versus mastery of competencies evaluation continuum. Source:own elaboration.

In the left level, organizations place great importance to the acquisition of knowledge and the courses are in the traditional format. However, the curriculum is organized around competencies. In the center level, there is a relative equilibrium between knowledge and competency evaluation. It is like a hybrid approach where students attend courses to learn content and, on average, $50 \%$ of the class assessment is direct, i.e. earn credits based on the 
mastery of competencies. Finally, in the right level, students do not attend traditional courses and the evaluation is 100\% of competencies (CRACUS, 2015; Tracy, 2016).

\section{CBE Model Analysis of Main Universities and Colleges Worldwide}

An analysis of the $C B E$ models of main universities and colleges worldwide categorized on the levels previously described is presented below. The organizations were selected based on their mention in previous researches on the subject. Also, the level of $C B E$ implementation was analyzed to exhibit the most representative ones. Finally, consultations with experts of our institution were performed to determine the accuracy of the choice.

\subsection{Low Level CBE (80\% Content Evaluation / 20\% Mastery of Competency)}

Delaware County Community College (United States). This college has taken the basic approach of $C B E$. It has identified 10 general competencies to develop: Proficiency in mathematics, reading, writing and speech communication, Concept of self, Apply the meaning of career, Lifelong learning, Decision-making, Arts and humanities, Social, political, business and economic systems, Science and technology, Critical thinking and technology skills and Diversity. Techniques for teaching them include: interships and paid work (DCCC, n.d.). The competencies are incorporated in the curriculum and there are no specific methods of assessment. Teachers are not required to document them (Klein, 2012).

Lingnan University (China). This university is new at incorporating CBE (Lui \& Shum, 2012). The general competencies that undergraduate students must acquire are 7: Independent and critical thinking, Creativity and innovation, Communication, Social responsibility, Personal virtue, Cultural accomplishment and Passion for lifelong learning. Their teaching techniques consist on field trips and discussion; the assessment is done through standard tests (Lingnan University, 2016b). The expected abilites are learned during the whole career, through 11 courses and extracurricular events (Lingnan University, 2016a).

National University of Singapore (Singapore). NUS encourages undergraduate and graduate students to develop 6 competencies: Questioning minds, Well-rounded mind, Constructive and responsible, Global citizens, Resourceful and enterprising spirit and Communicators. This is achieve through formal and informal education inside and outside the classroom, with techniques such as attend seminars and study trips. These competencies are taught in 5 modules and some flexibility is offered. There is a continuous assessment for students, which constitutes a percentage of the final grade (NUS, 2016).

Alverno College (United States). This college incorporates 8 competencies in both undergraduate and graduate curriculums: Communication, Analysis, Problem solving, Valuing in decision making, Social interaction, Developing a global perspective, Effective citizenship and Aesthetic engagement. The main outcome is to make students continuous 
learners. Competencies are defined in developmental levels (Alverno College, 2016). The teaching techniques include simulations and case studies. Evaluation is done through the observation of mentor and student self-assessment. Also, a narrative transcript is given, not a grade (Alverno College, n.d.).

\subsection{Medium Level CBE (50\% Content Evaluation / 50\% Mastery of Competency)}

Marylhurst University (United States). This univesity offers undergraduate programs in which graduation is achieved by a hybrid fulfillment of requirements (Klein, 2012). The developed competencies are 10: Inquiry, Critical thinking, Intellectual breadth, Ethical action, Communicate effectively, Integrate new learning, Interact in a global society, Solve problems creatively, Skillfully weigh complex options and Make effective decisions. Students must complete a set of 19 courses aim at developing such abilities. Teaching techniques include internships and analytical writing. The evaluation is made through a Core Project (Marylhurst University, 2016). Students also have to pass traditional coursework.

Wirral Metropolitan College (United Kingdom). This college offers careers in which technical knowledge is acquired and specific competencies of the choosen program, e.g. Team leading and Presentation skill, are incorporated in the curriculum. Students learn independently and assessment methods include assignments and/or open book exams (Wirral Met, 2016). Some used teaching techiques are enterprise challenges and simulations (Wirral Met, n.d.). To gain the final certification, in some cases, Pearson tests are used.

\subsection{High Level CBE (50\% Content Evaluation / 50\% Mastery of Competency)}

Western Governors University (United States). WGU main target market is the busyworking adults. Students are not required to pass topic courses, they earn the degree based on the demonstration of competencies. They study at their own speed, taking evaluation when they consider convenient (Klein, 2012). Competencies to be mastered are incorporated in the curriculum, e.g. Critical thinking, Logic, Problem solving, Effective communication, Leadership and Strategic thinking. Teaching techniques include activies such as write papers and do oral presentations. Assessment is done by completing practical assignments and standard tests (WGU, n.d.).

Holland College (Canada). Each program is developed around identified competencies by analysing the National Occupational Classification. Competencies are incorporated in the curriculum, e.g. Critical thinking, Literacy, Numeracy, Teamwork, Problem solving, Time management, Communication, Gender and cross-cultural sensitivity and Professionalism. Some teaching techniques are laboratories and real life situations. The learning is personalized, students develop a career plan with the aid of their mentor. Assessment is 
done through evidences and observation. Holland College offers a Prior Learning Assessment process aimed at experienced persons (Holland College, n.d.).

Charles Sturt University (Australia). $C S U$ students are prepared to work. The general competencies to be developed in undergraduate and graduate students are 9: Professional practice, Academic literacy and numeracy, Information and research literacies, Digital literacies, Ethics, Lifelong learning, Indigenous cultural competence, Global citizenship and Sustainable practices (CSU, n.d.). These are incorporated in the curriculum and some learning techniques are workplace learning, role play and scenarios. The assessment is a rubric based and feedback sessions are included (CSU, 2016).

Tampere University of Applied Sciences (Finland). It has a $C B E$ curriculum and the education is personalized. Students begin by developing a study plan with the advice of their mentors. The competencies to develop are incorporated in the curriculum and are specific of each program, e.g. Receptiveness to change, Time management, Ability to interpret information, Work in multicultural environments, Problem solving, Lead people, Be creative innovators and entrepreneurs. Teaching techniques include lectures and participate in R\&D projects in enterprises. Evaluation is based on rubrics (TUAS, 2016).

University of Wisconsin Flexible Option (United States). This university offers a flexible and affordable college experience to working-busy adults (University of WisconsinMadison, 2013). Competencies are incorporated in the curriculum and are specific of the chosen program, e.g. Interpersonal skills, Project scope analysis, Risk analysis and Personal selling. Teaching techniques include: essays and recorded presentations. Evaluation is direct, done through tests, observations and rubrics. Students with competencies learned previously can take an assessment and gain the credits (University of Wisconsin System, n.d.).

University of Michigan (United States). This organization offers the Master of Health Professions Education focused on $C B E$ (Observatorio de Innovación Educativa, 2015). To gain the degree, the learner must complete activities that a health professional educator will perform at work. Specific competencies of the program are developed, e.g. Educational methods and Personal leadership skills. To learn and practice them, the student must perform activities such as to criticize a curricular change. Evaluation is done through a documentation and evidence process (University of Michigan n.d.).

Low level $C B E$ organizations have mainly defined general competencies. These are developed both in specific clasess or incorporated in the curriculum. Medium level $C B E$ have mixed results. In one organization, competencies are specific of each program and hence developed embedded in the curriculum. The other has defined general compencies for its students, which are taught in particular courses. In high level $C B E$, the majority of 
organizations have defined specific competencies for each program, which are developed implicitly into the curriculum.

\section{State of the Art}

Taking in consideration the previous analysis of $C B E$ universities/colleges, the main up to date practices are described. The general competencies promoted ranges from 6 to 10 . However, the quantity of abilities can be high in colleges, as these are more specific. Figure 2 presents the general competencies most often developed, emerging general competencies worth noting and examples of teaching methods.

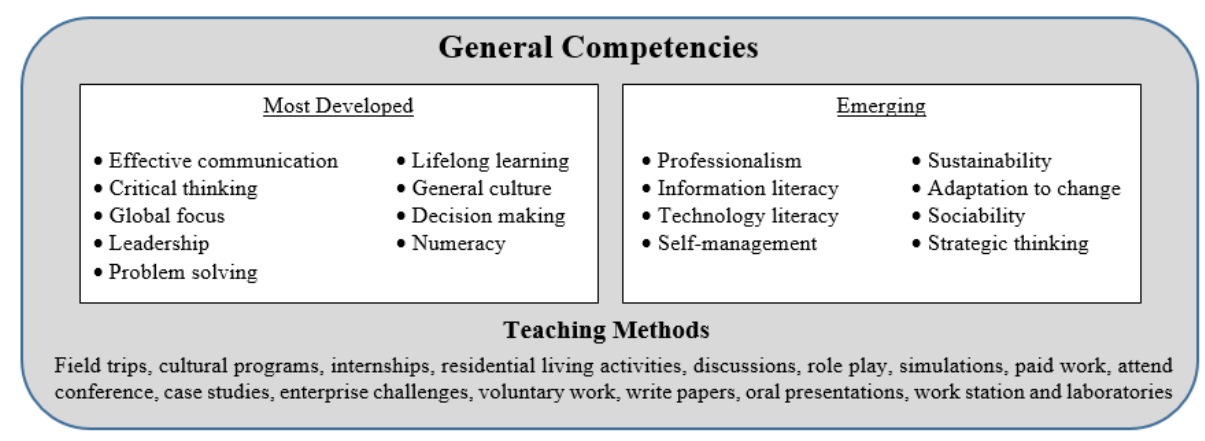

Figure 2. General competencies, emerging competencies and teaching methods. Source:Own elaboration.

Table 1 shows the competency development formats, examples of evaluation methods and how the students' progress is reported by the organizations under study.

Table 1. Competency development formats, assessment methods and progress report

\section{Development formats}

a) In specific courses, e.g. Lingnan University develop competencies in 11 courses

b) Embedded in the curriculum, competencies are acquired during the whole program

\section{Assessment methods}

a) Standard test, e.g. Information Technology Fluency Test and Pearson vocational tests

b) Evidences, e.g. papers published, grant applications, video presentations

c) Rubrics, portafolio of projects, mentor observation

\section{Progress report}

a) Pass or not pass grade

b) Narrative transcripts

c) Oral and written feedback 
In the QS Graduate Employability Ranking 2017 (QSIU, 2017) the organizations under study that appear and ranked higher are: NUS (\#21), University of Michigan (\#27) and University of Wisconsin (\#91). NUS main education characteristic is flexibility with intellectual rigorousness. It is commited to develop competitive students. Proof of the above is that it is continuously scanning what happens in the industry, through the Centre for Future-ready Graduates, wich main goal is to develop students with the demanded skills by the worldwide productive sectors (CFG, n.d.).

$C B E$ approach of organizations analysed gives important benefits under student's perspective, e.g., some Marylhurst University graduates argue that flexibility is a value added. Also, they were able to apply the learned concepts immediately at work (GradReports, n.d.-a). In $W G U$, one important advantage for the students is gaining credits from previous experience, which speed up graduation. Besides, they can balance academic, personal and laboral life (GradReports, n.d.-b). According to University of Wisconsin Flexible Option students, $C B E$ approach let them improve current job skills in a short period of time. Also, the investment is relatively low, having a good return on it (University of Wisconsin System, 2014).

\section{Conclusions}

$C B E$ is an educational approach with emphasis on outcomes. Its main advantage is that measures what a student can do after completing a program. $C B E$ is quite flexible, universities/colleges of any size/age can incorporate it, depending on their resources and strategies. Universities/colleges from different countries were analyzed; they exhibit different levels of $C B E$ implementation, ranging from those having a traditional curriculum, with competencies being a minor part of evaluation, to those in which the mastery of solely the competencies is the main goal. Universities seem to have well defined general competencies to promote. They vary from 6 to 10, and are mostly taught in specific courses. In colleges, competencies are specific of each course/program and are embedded in the curriculum. Competencies such as effective communication and global focus are mostly promoted. However, there are other interesting ones: self-management and sociability.

\section{References}

Alverno College. (n.d.). Our Unique Curriculum. Jul 13, 2016, www.alverno.edu/academics/ouruniquecurriculum/

Alverno College. (2016). Ability-based Learning Program. Milwaukee. www.alverno.edu/ability-based-learning-2016.pdf

CFG. (n.d.). What We Do. Jan 29, 2017, www.nus.edu.sg/cfg/

CRACUS. Regional Accreditors Announcement (2015). US. www.nwccu.org/Standards and Policies/Policies/PolicyDocs/C-RAC CBE Statement Press Release 6_2.pdf 
CSU. (n.d.). Graduate Learning Outcomes. Mar 30, 2017, www.csu.edu.au/division/student-learning/home/csu-curriculum

CSU. (2016). Assessment and Moderation. Jul 4, 2016, www.csu.edu.au/division/studentlearning/home/assessment-and-moderation

Dawson, D., Dean, J., Johnson, E., \& Koronkiewicz, T. (2014). Competency-based Education: Closing the Completion Gap. At Issue, 4(1), 1-8.

DCCC. (n.d.). Course Catalog 2014-2015. www.dccc.edu/academics/courseinformation/college-catalog

GradReports. (n.d.-a). Marylhurst University Reviews. Mar 29, 2017, www.gradreports.com/colleges/marylhurst-university

$\begin{array}{lllll}\text { GradReports. } \quad \text { (n.d.-b). WGU 29, } & \text { Reviews. }\end{array}$ www.gradreports.com/colleges/western-governors-university

Hernández, M., \& Morales, R. (2016). Current Trends in Competency Based Education. World J of Eng and Technology, 04, 193-199.

Holland College. (n.d.). Holland College. Jul 13, 2016, www.hollandcollege.com/

Klein, R. (2012). Competency-based Degree Programs in the U.S.: Postsecondary Credentials for Measurable Student Learning and Performance. www.cael.org/cbepublications

Lingnan University. (2016a). Core Curriculum. Jul 12, 2016, www.ln.edu.hk/ccgeo/corecurri.php

Lingnan University. (2016b). Undergraduate Prospectus. www.ln.edu.hk/admissions/ug/prospectus/prospectus.pdf

Lui, G., \& Shum, C. (2012). Outcome-based Education and Student Learning in Managerial Accounting in Hong Kong. J of Case Studies in Accreditation and Assessment, 2.

Marylhurst University. (2016). Marylhurst Core. Jun 30, 2016, http://catalog.marylhurst.edu/content.php?catoid=8\&navoid=831

NUS. (2016). NUS Bulletin AY2016/17. Jan 29, 2017, www.nus.edu.sg/nusbulletin/

Observatorio de Innovación Educativa. (2015). Educación Basada en Competencias. https://observatorio.itesm.mx/edutrendsebc/

QSIU. (2017). QS Graduate Employability Rankings 2017. Jan 29, 2017, www.topuniversities.com/university-rankings/employability-rankings/2017

Tracy, R. (2016). Is There a Continuum for Competency-based Education? Jun 28, 2016, http://evolllution.com/programming/applied-and-experiential-learning/is-there-acontinuum-for-competency-based-education/

TUAS. (2016). Curricula. Jul 4, 2016, http://ects-guide.tamk.fi/opetussuunnitelmat

Umbleja, K., Kukk, V., \& Jaanus, M. (2013). Competence-Based Approach to Learning. 2013 IEEE Global Eng Education Conf (EDUCON) (pp. 552-559). Berlin.

University of Michigan. (n.d.). Master of Health Professions Education. Aug 12, 2016, http://lhs.medicine.umich.edu/education/mhpe

University of Wisconsin System. (n.d.). UW Flexible Option. Jul 19, 2016, http://flex.wisconsin.edu/ 
University of Wisconsin System. (2014). Why One Busy Nurse Chose the UW Flexible Option Program. Mar 29, 2017, https://flex.wisconsin.edu/blog/one-busy-nursechose-uw-flexible-options-rn-bsn-program/

University of Wisconsin-Madison. (2013). Campus and Visitor Relations. Aug 10, 2016, https://kb.wisc.edu/vip/page.php?id=28325

WGU. (n.d.). Western Governors University. Jul 12, 2016, http://www.wgu.edu/

Wirral Met. (n.d.). Wirral Metropolitan College. Jul 13, 2016, http://wmc.ac.uk/

Wirral Met. (2016). BTEC Higher National Certificate (HNC) in Manufacturing Engineering E155. Jul 1, 2016, http://www.wmc.ac.uk/course/38307 